\title{
The Value of Narrative in al-Bayātī 's Broken Pitchers
}

\author{
Khalid Muhammed Saleh ${ }^{1 *}$, Ali Abdul-Raheem Kareem ${ }^{2}$ \\ 1,2 Department of Arabic Language, Faculty of Education, University of Misan, Iraq \\ *dr-khalid@uomisan.edu.iq
}

\begin{abstract}
The subject of our study is the narrative techniques in the poetry of "Abd al-Wahhāb al-Bayātī (1926-1999) which were taken into account through the example of his second published works Abārīq Muhashshamah "Broken Pitchers, 1954", as narration. The aim of the article is to define the features of narration and how the same techniques appear in creative work of a poet, one of the pioneers of modernity in contemporary Arabic poetry, in addition to Badr Shākir al-Sayyāb (1926-1964), and Nāzik al-Malā'ikah (1926-2007). The study defines the following objectives: Determining the approaches developed in studying the aspects of narration in poetry, to distinguish the narrative examples in the modern poetic text under study; To show the process of creating the poetic genre in the Bayati literature through the example of free verse poems. This article seeks, through the methodological principles of narrative research, to reveal the features of the narrative model that organizes communication in al-Bayāti 's poetry, as well as the features of the composition of the narrative structure of the text in al-Bayâtī 's collection Broken Pitchers. The article analyzes the poetic texts and their intertwining with prose, as it tries to uncover the narrative and performance discourses from which the poet set out in determining the techniques of narration he uses, the communicative possibilities such as dialogues and the narrator's point of view in the poems at al-Bayātī.
\end{abstract}

Keywords

narrative, 'Abd al-Wahhāb al-Bayātī, contemporary Arabic poetry

Article Received: 18 October 2020, Revised: 3 November 2020, Accepted: 24 December 2020

\section{Introduction}

One of the main problems in studying the origin of modern Arabic poetry remains the question of how individual creative art forms and poetic features were formed and how free verse poets established themselves. This topic is a particularly renewed question for researchers in modern literature, as poetic genres have been formed according to unique rules, justified by the active association of traditions inherited in Arabic literature and the experience of benefiting from foreign literature.

The fundamental factor in establishing poetic art is the defining features of the author's worldview. Hence, the important question in the study of poetic origin is to describe the mechanisms related to culture in terms of the relationship between text and literary genres for the establishment and formation of categories of authorship. The composition of authorship and the creative poetic features of al-Bayātī literature are related, first and foremost, to the literary legacy of poetry and prose written in the Arabic language.

In the early period of his creative writing, when he published his first works, al-Bayātī focused on the romantic dimensions and the self was spaced in the forest and the dream. There are several justifications for this: The first is that his first works were an expression of an imagined world that breathed his last breath as the poet himself expressed this (al-Bayātī, Tajribati al-Sh'irī yyah (My Poetic Experience), 1968); The second is the general atmosphere in which the poet wrote poems.

Meanwhile, after publishing Abārīq Muhashshamah "Broken Pitchers, 1954", in his creative outlook, Al-Bayātī was looking for genre forms aimed at his readers, not a single or local reader, but a mass reader. The poet worked on written representations of his creative writings, and the metaphor of narrative techniques of the contemporary poem witnessed the re-processing of the creative material in terms of its unity in form and content. This indicates that the author consciously took these specific steps in composing the poetic text. 


\section{Research problem}

Al-Bayati's first published work revealing his poetic beginnings and the strategies he dealt with in formulating his speech is his first collection, Malā'ikah wa Shayātīn "Angels and Devils, 1950", and four years later he published his second collection Broken Pitchers. The publications of his early works clearly illustrate the process of his transition "from experimentation to poetry, as Ihsān `Abbās points out, for example issued immediately after" Broken Pitchers ", and devoted it mainly to the study of this group. 'Abbas said about this surprising grandmother, and said: "What al-Bayātī wanted to achieve is not an effort - he wanted the grandmother all at once, in the image, the subject and the tone." ('Abbās, 1955) 'Abd al-Wāhiid Lu'lu'ah adds to the innovation that Abbas pointed out to another element reflected in alBayātī i's poems "in his second collection "Abārīq Muhashshamah" rushing into an unexpectedly developed column style, although Al-Bayātī did not study European literature in its original languages, but he opened up too many cultures since his early reign in poetry" (Lu'lu'ah, 1974)

What 'Abbas and Lu'lu'ah sees is confirmed when they talk about innovation and novelty, and is influenced by the experiences of Western poets, when the reader moves from "Angels and Devils, 1950" to "Broken Pitchers, 1954", and suddenly finds himself faced with a new poetic formulation completely different from the poetic art in neoclassical poetry and romantic poetry as such. whether. In "Angels and Devils, 1950", the poet appears to be the central figure in the poem, expressing his subjective emotions in it, describing what is around him with the eyes of himself, so that he makes everything on him what is inside him or in Broken Pitchers, the poet becomes more like a narrator in fictional art, presenting his images and positions in the form of objective narration, which is a feature that completely dominates the whole group of Broken Pitchers.

It should be noted that in his early creative works, the author created a special type of poetic text aimed at narration, which later became his distinctive style that encompasses his entire creative path, but most of the critics who paid attention to this path that al-Bayātī took in his poems did not study it in The light of the narrative theory, but they interpreted its presence according to the data of the concept of artistic image that has become common in Western criticism, based on Elliot's poems and criticism. Ihsan 'Abbas, for example, devoted an entire chapter of his book to the study of the image in jugs, so he clearly distinguished between two types of images: wide pictures, whose parts are usually formed from the perspective and the audible, as in the village market, for example, and the long image that revolves around one person, in which his concerns and pain echo. So that it becomes closer to the inner monologue, as in the poem of al-Malj'aa alIshron" The Twentieth Refuge" and al-Qursān "The Pirate".

Given the fact that the synthesis of narrative and poetic mechanisms to create the text plays an important role in 'Abd al-Wahhāb al-Bayātī poetry, where narration performs one of the main text-forming functions, analyzing his poetry as a poetic narrative system allows giving a new perspective from his creative principles and reading his poetic texts. In this respect his work appears in jugs shattered; The structure of this creative piece of writing combines two opposing forms of storytelling - poetry and prose, as this demonstrates that there was a process of developing a narrative strategy in the early creative writings of the 'Abd al-Wahhāb alBayātī.

\section{Methodology of the research}

Although Roland Barthes realizes that the narrative is international and cross-border, and that no group or social class does not know or produce narration (Barthes \& Heath, 1977), McHale believes that looking at the relationship of narration with poetry is like looking at a black spot; Because the history of literary theory has 
remained silent and hardly anything appears except silence in narrative theory in dealing with the presence of narration in poetry (McHale, 2009).

Hayden White may seem right in his reading of Barthes's opinion on the relationship of narration to experience, and how the language of narration represents a reproduction of the event that represents the experience of the poet, White sees that as Barthes says, between our experience of the world and our efforts to describe that experience in language, narrative ceaselessly substitutes meaning for the straightforward copy of the events recounted." And it would follow, on this view, that the absence of narrative capacity or a refusal of narrative indicates an absence or refusal of meaning itself" (White, 1981).

But how was this meaning perceived in the narrative? Rick Altman replies that the narrative makes sense largely in terms of characters and their actions but texts are understood as narrative only through systematic reference to their character/action complex. This tendency to make meaning in a par tic u lar way is exactly what we acknowledge in recognizing a text as narrative. As we devise a critical language appropriate to narrative mapping, two basic principles must then be taken into account: narrative meaning arises from character/action considerations, and narrative meaning depends not on single character/action units but on relationships among units (Altman, 2008). This new concept of narration in contemporary theory, which is based on eliciting narrative connotations through the relationships between the constituent units of the narrative, made Mieke Pal saw narration as a cultural attitude; hence, narratology is a perspective on culture (Bal, 2017). What he proposes we are best off within the age of cultural analysis is a conception of narratology that implicates text and reading, subject and object, production and analysis, in the act of understanding. In other words, I advocate and offer a narrative theory that enables the differentiation of the space of narrative in any cultural expression without privileging any medium, mode, or use; that differentiates its relative importance and the effect of the narrative (segments) on the remainder of the object as well as on the reader, listener, viewer.

If we look at the relationship of narration to poetry according to the premises that Altman and Pal focused on, and taking into account the black spots that McHale spoke about, we will fully agree with Didier Coste's opinion that it is highly confusing to treat "narrative" as a "genre" on the same plane as poetry, the fable, the sermon, the manifesto, or the minutes of a meeting, since it can occur in any of these genres and it must in a number of them; in other words, narrative meaning can or must arise in any number of genres so determined, which are genres of texts (Coste, 1989). There is no doubt that what Coste is referring to in trying to find the meaning of narration through textual pluralism raises a concern that causes both Gerald Prince and Arlene Noble to reconsider how to find the meaning of narration, and it centers on narratologists must take into account the possible alethic differences of the worlds and statements constituting the narrative text as well as the type of textual contributions asked of a receiver. "It is on this condition that they (that we!) will be able to explain the semantic functioning of narrative and to make narratology fit into a general semiotics" (Prince \& Noble, Narratology, Narrative, and Meaning, 1991)

All that modern narrative theory points to is almost a fulfillment of what Gerard Genet and Jean E. Lewin said forty years ago that the level of narrative discourse is the only one directly available to textual analysis, which is itself the only instrument of examination at our disposal in the field of literary narrative, and particularly fictional narrative. (Genette \& Lewin, 1980)

One might agree with Brian McHale's argument that contemporary narrative theory's relative neglect of poetry appears not so much an oversight as a scandal; because he argues that "there would be no tradition of systematic 
reflection on narrative at all, at least not in the West, without the Homeric poems, which, from Plato on down to Genette and Sternberg and beyond, have continuously served as touchstones of narrative theory. Many important theoretical developments have hinged on analyses of poetic narratives; for instance, it would be hard to imagine Bakhtin finding his way to a theory of discourse in the novel without the example of Pushkin's Onegin" (McHale, 2009)

\section{Discussion}

\section{The Poem and the Elements of Narrative Construction: Poet's choice}

1.1. Character: The character is an important element in the literary text, as Tomashevsky says: "the character is a guiding thread which makes it possible to untangle a conglomeration of motifs and permits them to be classified and arranged. Then too, there are devices which aid in untangling the groups of characters and their interrelations. The reader must know how to recognize a character, and the character must attract at least some attention." (Tomashevsky, 1965) In the modern narrative, Barthes acknowledges the dominance of character over action when he says: that sequences, as independent blocks, are recuperated" at the higher level of the Action (of the characters)" (Barthes \& Heath, 1977). Wallace Martin argues that characters in the narration do not take a single form or a fixed position, but rather their states change, and this change has nothing to do with action, he says:" Characters are not, then, mere collections of attributes... They may remain static, change gradually, undergo a transformation, or never achieve self-definition within the limits of the narrative; though fused with the action, as Barthes and Tomashevsky suggest, they are not dissolved in it" (Martin, 1986)

According to (Chatman, 1978), characters can be more or less major or minor in terms of textual prominence, dynamic when they change or static when they do not, consistent when their attributes and actions do not result in contradiction or inconsistent, and flat simple, two-dimensional, endowed with very few traits, highly predictable in behavior or round complex, multidimensional, capable of surprising behavior. That they are also classable in terms of their actions, or their words, their feelings, their appearance, etc.; in terms of their conformity to standard roles or types; and in terms of their correspondence to certain spheres of action that of the hero or that of the villain, for instance or their concretizing certain actants the sender, the receiver, the subject, the object. (Prince, 1987)

The personalities that 'Abd al-Wahhāb al-Bayātī deals with in the poetic discourse are many, including real realistic personalities, heritage personalities, and mythical personalities. In broken jugs, characters appeared of various types, the most important of which are:

1.1.1. Fictional Character: it is the character that plays the role of the companion or the absent character of the narrator or is like a mask, and this type of characters gives the narrator a great ability to move as the area of interpretation and the ability to imagine and the desire to reveal and tell is expanded (Genette \& Lewin, 1980). The poet resorts to this style of characters to fulfill psychological desires that indicate his sense of being lost, and the poet resorts to being his character's dependent on another consciousness that takes hold of him when he finds reality lost, and tries to break the stillness and terror surrounding him by creating these characters and making them in the role of the narrator in the narration within the poem. This character has appeared in his collection "Broken Pitchers" in two types:

1.1.1.1. Anonymous Addressed Character: it is a character that is not defined by name or description, but is present as a recipient of the narrator's speech. Al-Bayātī used this to cast his anxiety on the character, or to express his views through it, and this type of characters may allow wide freedom of expression, criticism and ridicule that the poet benefits from it in broadcasting his 
vision. This type was mentioned frequently in "Intizar" (Awaiting), in his collection Broken Pitchers, he is so powerless that he asks the addressee back home to pray for him:

Pray for me!

Across the walls of my naked, hungry, sad homeland

And on the wharf, wait. (al-Bayātī, 1969)

It is noticed that the poet introduced the character without naming or giving any information about it. This character was also mentioned in Al'asir (Prisoner), where al-Bayātī addressed an unknown character that he called (my little angel):

My little angel, did you know the pain, and crying bitter tears?

Did you know passion and remorse!

Have you lived the suffering of the last way, and the damned boredom!

My little angel, did you know the pain? (al-Bayātī, 1969)

The poet uses the personality to cast upon it the experiences of suffering and anxiety by means of a question that does not want an interrogation, but an affirmation. In " al-Dhīb" (Wolf) the poet implores character that has no limits as it has no name except that it appears in a song that the poet hears from a radio, and while the poet makes the title of his poem the wolf, his speech throughout the poem is devoted to calling for belonging to humanity:

My only treasure! My dove, my dream

You are the sweetheart of my dark, culprit and my black sorrows!

Restore my humanity. (al-Bayātī, 1969)

This character also appeared in "Tāmmat 'Allubāh" (Game Over) :

Don't say "I love you"! When...! And where?

Don't say, "This is our destiny. Goodbye!

The pawn looks in fear and silence at us and the game is over. (al-Bayātī, 1969)

Anonymous addressed character has appeared strongly in the poems in which the function of the addressee is mentioned in collection (Broken Pitchers), and al-Bayātī used the Second Person Pronoun in discourse and narration.
1.1.1.2. Mentioned Invented Character: In the "Mao Mao" there is a character (Mary) and the narrator made himself a companion, and in the poem itself a reference to a blind girl he did not name:

My companion, Mary, is wrapping the head of a negro, who is wounded

And a blind girl, milking a goat, and out of the steppes they were like swallows, like chimneys they left. (al-Bayātī, 1969)

Among the characters that are added to this classification field is the character of (the mother), which appeared in several poems, including "alMalj'aa al-Ishron" (The Twentieth Refuge):

My mother! We are still fine, "and the wolves howl and howl in the desert of sleeplessness"

The character of (the mother) was also mentioned in the poem "The Wind of the South"

Our prayers, mom, for the new morning

Behind us the dogs howled, and from afar the slave land. (al-Bayātī, 1969)

Also in "al-Raheel al-Awal" (The First Departure) the mother character appears:

Even the extinguished candles in my abandoned bunk await the flames

And the shaky, weeping, gloomy imagination of my mother beckons me to come back. (al-Bayātī, 1969)

The character of the mother was like the refuge in which the narrator sought refuge, and that the poet intended from behind this multiple symbols, the most prominent of which is the homeland, and the mother's character came without qualities because she is perceived by the collective consciousness. It can be recorded that the mentioned invented character was distinguished by its wide presence, compared to the rest of the characters, and this reflects the presence of psychological desires of the poet, such as revelation and discourse, as well as the poet's sense of loss and despair.

1.1.2. Historical Characters: They are historical or religious characters, that contribute to creating a narrative rhythm and a large narrative space that enriches the poetic text and gives it aesthetic 
characteristics. The poet may add contemporary data to the historical personality while preserving its inherited image. In the poem, the narrator creates two opposite times in order to facing the character. This type of character was present in the poem "Việt Minh", in which the character of the German Nazi Party leader and politician (Adolf Hitler) appeared:

Cursed bitch "Hitler" still scares people:

There is no glory except the glory of the children of life, the bread and the revolutionaries, country of darkness! (al-Bayātī, 1969)

The character (Hulagu Khan), in which a Mongol ruler who conquered much of Western Asia after killing millions of its people, mentioned in "al-Aiddon" (The Returners)

Hulagu's eyes dry their shine

The restriction is broken by slaves. (al-Bayātī, 1969)

The poet also mentioned the character (Hulagu) in the poem "Harem" (Seraglio), as well as the presence of the character (Hārūn Ar-Rašīd) who was the fifth Abbasid Caliph:

And they practice fake saying, comrade

"Hulagu" and "Hārūn Ar-Rašīd" are still in the trade of slaves and false speech

And the "poor of Makkah" were still on the way. (al-Bayātī, 1969)

The poet invested what was known about these two characters in a way that fits his text when criticizing the blood merchants, those with false sayings, and he did not present qualities to them, but the two personalities provided the text with information because they are present in the collective consciousness.

1.1.3. Mythical Characters: is the character who refers to a full and fixed meaning defined by a culture, as well as to fixed roles, programs and uses. Reading this character and knowing its role in the narration is related to the reader's degree of understanding of this culture. The mythical character appeared in "Fi al-Manfā" (In Exile), where the mythical character (Sisyphus) appeared: The deaf rock, rolled by slaves to the valley Sisyphus is resurrected, in the form of a homeless exiled man. (al-Bayātī, 1969)

The poem's title (In Exile) suggests isolation and exile, and the poet's attempt to get out of his exile made him seek the help of the mythical character of Sisyphus in Greek mythology. God has tied Sisyphus' fate to a rock to roll, but 'Abd alWahhāb al-Bayātī makes exile a bond for the poet. References provided by the character of Sisyphus helped the poet to bring the image of negation and loss close to understanding.

1.2. Space: There are characters which have a capacity for movement and there are those which are, so to speak, tied to their spaces. Space is a group of homogeneous things (from phenomena, states, functions, or changing forms ... etc., between them are relations similar to the usual spatial relations / normal, and the space is a social entity that contains the summary of the interaction between a person and his community, and it is like any other social product that carries Part of the ethics and awareness of its inhabitants, and the space may constitute a material base upon which the poetic scene is based.

The concept of space has witnessed a development in modern critical curricula. New poetics focused on the space by making use of semiotics and human sciences, drawing attention to its importance in analysis and research. Gaston Bachelard is the most prominent person interested in studying space, says: "the space that is polarized by the cellar and the attic, to see how this polarized space can serve to illustrate very fine psychological nuances" (Bachelard \& Jolas, 1994). The poet or the narrator in poetry deals with a space that may be strange to the narrator and the characters, and the space may be familiar, and he notes in the modern poem the poet's dependence on framing the poem's events spatially, to interact with places, diagnose them, and stain them with the color of humanity. The place will be analyses in the al-Bayātī collection in terms of the opposites: strange/ familiar, and the humanized space.

The Opposites: Strange/ Familiar: 
For al-Bayātī, space is identity and belonging, and the reader of his collection Broken Pitchers clearly finds the poet's nostalgia for a place or his aversion to it, and based on the foregoing, the study will stop at the familiar place and the strange place.

1.2.1. Strange Space: These spaces abounded in jugs, and this showed the poet's alienation and his aversion to most of the spaces that came under different names, including:

1.2. 1.1. Wall: The wall is one of the most popular places in al-Bayātī's poems, as it embodies the harshest images of rejection, and was associated with sadness, dispersion and loss. It is a strange place par excellence. The wall came in several poems, including " al- Mahrāqah" (the Holocaust):

For light and darkness, my gates.

The trivialities are behind our wall listening to the dead with admiration (al-Bayātī, 1969)

The wall appears here as a dividing line between the poet and his people and what he describes as "trivialities", as well as the wall in al-Bayātī's poem (The Twentieth Refuge):

Our blood is still spilled

Our old walls, and our barren fields, are invaded by locusts and thieves (al-Bayātī, 1969) In "Oshāq fi al-Manfā (Lovers in Exile) the narrator expresses his hate which he ascribes to the wall and expresses his misfortune at the existence of the wall:

Nothing comes alive. These obnoxious walls and paths

The hapless in these paths (al-Bayātī, 1969)

Elsewhere in the same poem, the narrator mentions the wall:

Like you and me, they dig their graves through the wall (al-Bayātī, 1969)

And in the "al-Hadīqa al-Mahjorah" (Abandoned garden) the wall is present:

The echoes echo: "The North Wind!"!

On the walls, ivy dominated depression, like pimples (al-Bayātī, 1969)

The wall here is the specific, closed place, which robbed the poet and his companions of the free people, and the wall embodied sadness and blood in the poem.

1.2. 1.2. Prison: Prison appeared as a strange place, a space where freedom was restricted, and there were no actions in it. Prison was mentioned in the "Sārīq al-Nār" (Thief of Fire):

There is still a smell in the black prison, and in the shelters of his bad history (al-Bayātī, 1969)

The prison also stated in "al-Sājīn al-Mājhoul" (Unknown Prisoner):

Through the prison door, through the darkness our hut shine and death, and the stars (al-Bayātī, 1969)

The title of the poem, which refers to the unknown prisoner, because prison is a place that neglects character and isolates it from the world, as it is a strange place, a restriction of freedom, and prison in general bears descriptions of sadness, blackness, darkness and restriction.

1.2.1.3. Exile: In "The Twentieth Refuge" the narrator tells about his exile:

Twentieth Refuge

We're still fine with children. Lice and the dead send their greetings to our relatives.

Crude distorted memories descend upon us (alBayātī, 1969)

Exile is the space that forcibly annexed the poet, and this is a strange space, and the descriptive painting in the poem showed the intensity of the suffering mentioned by the narrator in the poem.

1.2.2. Familiar Place: It is characterized by values of protection, safety and containment, Gaston Bachelard described familiar place as being behind all the positive values of protection, the house in which we were born becomes saturated with the values of dreams that remain after the demise of the house (Bachelard \& Jolas, 1994)

1.2.2.1. Homeland: homeland at al-Bayātī is the identity of the poet and his constant nostalgia for the space he was deprived of in order to live in exile, and the space is restored and the call for nostalgia for him in a psychological atmosphere and subjective suffering that the narrator goes through, such as fatigue. In "Intizar" (Awaiting), 
in his collection (Broken Pitchers), al-Bayātī is so powerless that he asks the addressee back home to pray:

Pray for me!

Across the walls of my naked, hungry, sad homeland (al-Bayātī, 1969)

This homeland evokes nostalgia and longing for people and scenes. Every detail is recollected in that pivotal crossing where memory gets entrenched. In the poem "The First Departure" alBayâtī repeated the call to pray for him while he was in exile, and this time the narrator invites his mother to pray for him:

Pray for me, Mama! for my faraway country (alBayātī, 1969)

A homeland, which represented a familiar space for the poet, became a strange place at the same time, due to certain circumstances such as colonialism and wars, and here we understand that nostalgia remains with the poet whenever the homeland is mentioned. In addition to the explicit expression of the place, the poet uses other symbols that denote the homeland, such as mother or beloved. Fiction has given space the opportunity to shift from the strange to the familiar, and this is one of the advantages of narrative space that Bachelard wrote:" The imagination, by virtue of its freshness and its own peculiar activity, can make what is familiar into what is strange. With a single poetic detail, the imagination confronts us with a new world" (Bachelard \& Jolas, 1994)

1.2.2.2. The city of Jaffa: Jaffa is a city from which its people were abandoned, where the narrator talks to it in the poem "The Twentieth Refuge" with a promise to return to it, accompanied by all the exiles and prisoners.

Death to every coward and servile!

Jaffa! We come back tomorrow with the harvest

With a swallow and spring

With comrades returning from exile and prisons. (al-Bayātī, 1969)

Thus it becomes evident that the closed space such as the wall, the prison and the shelter represented a strange space, while the open space represented a familiar space, and in general, the closed space prevailed in Broken Pitchers, and other spaces such as the countryside, the village, the city and the hut were mentioned, but the poet did not elaborate in its description, but added one characteristic. As well as it appeared once as a pet space and strange space again

1.2.2.3. The Humanized Space: al-Bayātī borrows human characteristics in some spaces, as is the case in the poem "After Spring", which is formed from a human painting in which space and time are present:

The earth takes pride in its spirit and refuses to be aware of its misery to the monsters of the city

The nights of deprivation died and then we lived quietly awaiting death

Tomorrow autumn breaks up the ground and scatters its strong husk (al-Bayātī, 1969)

In poem "'Amtār" (Rain) the poet makes the place and time with all the characteristics and natures of man:

On the day the sky threw rain on the earth, the village and time slept. (al-Bayātīi, 1969)

Likewise, in the poem "Suq al-qaryah" ("The Village Market") the place seems to celebrate its human nature:

The deserted market, and the small shops,

And the flies,

Hunted by children,

And the distant horizon,

And the yawning of huts in the palm-grove. (alBayātī, 1974)

1.3. Anachrony: It means the study of time according to its movement forward or backward, and Gérard Jennet defines it as: the system of arranging events or syllables in progress or backward (Genette \& Lewin, 1980), but Todorov believes that the time of speech and the time of imagination cannot be parallel due to the interferences of pre, distance, previous and subsequent (Todorov \& Howard, 1978). These interventions are due to the different nature of the two times, and the impossibility of paralleling them leads to the production of two paradoxes: analepsis and prolepsis. 
1.3.1. Analepsis: The presentation of events that have occurred before the current story-now. An external flashback presents an event occurring before the beginning of the primary story line (i.e., in the pre-history) (Prince, 1987). al-Bayātî used analepsis in the poem al-Qursān "The Pirate", which witnessed the old man's character recovering his memories:

Photos take it back, go back

To his island, its shore, thousands of ships, and men

Hookers in their well-worn clothes

They collect matches. (al-Bayātī, 1969)

Analepsis was also mentioned in the poem " Tāreq al-Hurriyah" (Freedom Path), which witnessed slaves recovering their behavior that contributed to the creation of tyrants:

We are the naked poor, Yesterday we enabled tyrants to build these bad destinies (al-Bayātī, 1969)

1.3.2. Prolepsis: presentation of a future event before its proper time. An external flash-forward involves an event happening after the end of the primary story line. An objective flash-forward or certain anticipation presents an event that will actually occur; a subjective flash-forward or uncertain anticipation is just a character's vision of a likely future event. (Genette \& Lewin, 1980)

Prolepsis is mentioned in the poem "Tāmmat 'Allubāh" (Game Over), where the narrator talks about his experience with the beloved, then predicts what the lovers' experience will be like from a similar to his experience:

We finished, "I buried our remains in my songs And tomorrow the game opens for other lovers They will see the fearful fawn (al-Bayātī, 1969) As stated in the poem " Affāq" (Deceptive):

Tomorrow she will lock her door in his face, and return to the gloomy café

It does not come back. (al-Bayātī, 1969)

The viewer of al-Bayātī 's poems in in his collection Broken Pitchers finds the domination of sadness over memories and events in analepsis, while he finds the domination of optimism and hope over prolepsis.
2. Narrative instances in "Broken Pitchers" 2.1. Tempo: a rate of narrative speed: ellipsis, summary, scene, stretch, and pause are the five major tempos in narrative (Prince, 1987). alBayātī uses specific techniques that speed up or slow down the narration:

2.1.1. Stretch: stretch obtains when discourse time is taken to be greater than story time, when a narrative segment is felt to be too, lengthy for the narrated it represents, and when a relatively long part of the narrative text corresponds to a relatively short narrated time to a narrated action that is usually completed in a short time (Chatman, 1978). To achieve stretch in narration of the poem, al-Bayātī found two paths: supplication and description. Narrator or the poet himself uses supplication in his poem "Thief of Fire". After narrating events about the despot, heroic age, and the world of the dead, he invokes a supplication:

I forgave them

I cried for them

I kept my shroud for them, Lord! (al-Bayātī, 1969)

In the poem "The Village Market," the narrator expands the narrative space or perhaps pauses completely by using the description of his girlfriend:

The eyes of my beloved are stars

And his breast is a bed of spring-roses (al-Bayātī, 1974)

2.1.2. Summary: one of the fundamental narrative speeds. when discourse time is smaller than story time, when a narrative segment is too brief for the narrated it represents, when a relatively short narrative text corresponds to a relatively long narrated time to a narrated action that it usually takes a long time to complete, summary obtains. This technique was used in the poem "The Unknown Prisoner", in which the narrator condensed events of four years into two lines of the poem:

Four years have passed and I am still in prison And my comrades are plowing the land in the far east 
And I'm still in prison singing (al-Bayātī, 1969)

The narrator also used summary technique in poem "The First Departure":

The night goes on and the day goes on

And I, alone, I travel in the open seas at sunset (alBayātīi, 1969)

2.1.3. Ellipsis: When there is no part of the narrative corresponding to narratively pertinent situations and events that took time, ellipsis obtains (Prince, 1987). This technique is mentioned in the poem "Musāfir bilā Haqā'ib" (Traveler Without Baggage), where thousands of nights or thousands of years were deleted without the narrator mentioning any information about it: There passed over me perhaps thousands of nights,

While in vain I heard her call in the wind-"come!" Across the hills.

I, and thousands of years,

Yawning, sad, bored,

From nowhere. (al-Bayātī, 1974b)

Ellipsis was also present in the poem "Ta'ifuhā" (Her Shadow), where the narrator deleted two years from the time of the story without mentioning anything about their events:

Spring came and left twice, and she did not put roses on my grave.

\section{Conclusion}

'Abd al-Wahhāb al-Bayātī's (1926-1999) second published works Abārīq Muhashshamah (Broken Pitchers, 1954) represented a structure that predetermined an existing balance between storytelling and performative discourse with the dominant role of construction and organization of the text. He presented a mixture of prose and poetic forms of creative discourse, narrative and non-narrative discourse in al-Bayātī 's poems in which he tried to build a text based on principles close to storytelling.

al-Bayātī created a synthesis of his work, consciously aiming to connect and balance the poetic and prose components in the minds of readers when he published this work that was formed as a textual unit.
In the early period of creative writing, al-Bayātī chose narrative discourse from all others. It appears that it is precisely this discourse that matches the intellectual and literary trends of his creative consciousness, as illustrated by his second published work, as he was able to combine clearly different lyrical discourses to develop strategies for narrative poetry.

Based on the methodological principles of narrative research, the features of the narrative example that organizes communication in alBayātī 's poetry are revealed, as well as the features of forming the narrative structure of the text at al-Bayātī. The syncretic nature of the composition of the work (a mixture of poetic and prose texts, narrative and performative discourses) became a starting point for the poet in defining narrative techniques, i.e. communicative possibilities (dialogues, the author's point of view), and narrative principles. Based on the tradition of storytelling from the daily reality in ancient Arab narratives, in addition to what appeared from the method of T. S. Eliot (1888$1965)$ in the modern poem, where contradiction is shown as an artistic method for organizing the text, etc.

The conclusions and other final notes presented in the article can serve as the basis for an in-depth study of the characteristics of the formation of a narrative principle in modern Arabic literature, and of theoretical and methodological developments that reveal specific narrative features in the texts of a contemporary poem.

\section{References}

[1] 'Abbās, I. (1955). Bayna 'Abd al-Wāhhmb al-Bayātī wa-T.S.Eliot. Al-Adīb, 27(3), 22-23.

[2] al-Bayātī, ‘. a.-W. (1968). Tajribati alSh'irī yyah (My Poetic Experience). Beirut: Manshurat Nizar Qabbani.

[3] al-Bayātī, ‘. a.-W. (1969). Abārīq Muhashshamah. Beīrut: Dār al-Adāb. 
[4] al-Bayātī, '. a.-W. (1974). "The Village Market" in an Anthology of Modern Arabic Poetry, ed. and trans., Mounah A. Khouri and Hamid Algar. Berkley, CA: University of California Press.

[5] al-Bayātī, ‘. a.-W. (1974b). "Traveler Without Baggage" in an Anthology of Modern Arabic Poetry, ed. and trans., Mounah A. Khouri and Hamid Algar. Berkley, CA: University of California Press.

[6] Altman, R. (2008). A Theory of Narrative. New York: Columbia University Press.

[7] Bachelard, G., \& Jolas, M. (1994). The Poetics of Space. Bosten: Beacon Press.

[8] Bal, M. (2017). Narratology: introduction to the theory of narrative. Toronto: University of Toronto Press.

[9] Barthes, R., \& Heath, S. (1977). "Introduction to the Structural Analysis of Narratives" In Image-Music-Text. London: Collins.

[10] Chatman, S. (1978). Story and Discourse: Narrative Structure in Fiction and Film. Ithaca: Cornell University Press.

[11] Coste, D. (1989). Narrative as Communication. Minneapolis: University of Minnesota Press.

[12] Genette, G., \& Lewin, J. E. (1980). Narrative Discourse: An Essay in Method. New York: Cornell University Press.

[13] Lu'lu'ah, ‘. a.-W. (1974). Al-Mu'atherāt Al-'Ajnabīah fī Al-Shi'r Al-'Arabī AlMuāsīr. Al-Adāb (6), 17-19.

[14] Martin, W. (1986). Recent Theories of Narrative. Ithaca: Cornell University Press.

[15] McHale, B. (2009). Beginning to Think about Narrative in Poetry. Narrative, 17(1), 11-30.
[16] Prince, G. (1987). A Dictionary of Narratology. Lincoln: University of Nebraska Press.

[17] Prince, G., \& Noble, A. (1991). Narratology, Narrative, and Meaning. Poetics Today, 12(3), 543-552.

[18] Todorov, T., \& Howard, R. (. (1978). The Poetics of Prose. Ithaca: Cornell University Press.

[19] Tomashevsky, B. (1965). "Thematics." In Russian Formalist Criticism: Four, ed. Lee Lemon and Marion Reis. Lincoln: University of Nebraska.

[20] White, H. (1981). "The Value of Narrativity in the Representation of Reality", in On Narrative, ed. W.J.T. Mitchell. Chicago: University of Chicago Press. 